Illinois State University

ISU ReD: Research and eData

Theses and Dissertations

$5-19-2017$

\title{
Children in Trouble with the Law and the United Nations Convention on the Rights of the Child
}

Jennifer L. Swick

Illinois State University, jlswick@ilstu.edu

Follow this and additional works at: https://ir.library.illinoisstate.edu/etd

Part of the Political Science Commons, and the Sociology Commons

\section{Recommended Citation}

Swick, Jennifer L., "Children in Trouble with the Law and the United Nations Convention on the Rights of the Child" (2017). Theses and Dissertations. 778.

https://ir.library.illinoisstate.edu/etd/778

This Thesis is brought to you for free and open access by ISU ReD: Research and eData. It has been accepted for inclusion in Theses and Dissertations by an authorized administrator of ISU ReD: Research and eData. For more information, please contact ISUReD@ilstu.edu. 


\title{
CHILDREN IN TROUBLE WITH THE LAW AND THE UNITED NATIONS CONVENTION ON THE RIGHTS OF THE CHILD
}

\author{
Jennifer L. Swick
}

\section{Pages}

Children in trouble with the law are the focus of much research in the US, but in expanding the scope to include these children across the world there are few studies can be found. The United Nations (UN) Convention on the Rights of the Child (CRC) articulates a set of universal rights for children. For children in trouble with the law, there are seven articulated rights across Articles 37 and 40; these are: protection against cruel, inhuman and degrading treatment or punishment; the right not to be detained in jails or prisons with adult convicts; the right to maintain contact with family members; protection against capital punishment and life without the possibility of release punishments; the right to an attorney or legal counsel; the right to a minimum age of criminal responsibility set by the government; and the right to a fair and speedy trial. This study used CRC country reports, non-governmental organization (NGO) supplemental reports, and Committee on the Rights of the Child's responses to the other reports to address the question, "What are the global range and patterns of national practices regarding children in trouble with the law?" Qualitative content analysis revealed that countries' overall reported compliance ranged from high-medium to low-medium, and that there was wide variation in the discussion of each of the 7 rights individually. Findings were connected to the literature on human rights treaty compliance, global children's rights, and research on Articles 37 and 40 of the CRC. 
KEYWORDS: Children's Rights, Global, Children in Trouble with the Law, International, United Nations Convention on the Rights of the Child 
ON THE RIGHTS OF THE CHILD

JENNIFER L. SWICK

A Thesis Submitted in Partial

Fulfillment of the Requirements

for the Degree of

MASTER OF SCIENCE

Department of Sociology and Anthropology

ILLINOIS STATE UNIVERSITY 
(C) 2017 Jennifer L. Swick 


\section{CHILDREN IN TROUBLE WITH THE LAW AND THE UNITED NATIONS CONVENTION ON THE RIGHTS OF THE CHILD}

JENNIFER L. SWICK

COMMITTEE MEMBERS:

Maria Schmeeckle, Chair

Thomas Gerschick

Noha Shawki 


\section{ACKNOWLEDGMENTS}

I would like to acknowledge the following people as this paper wouldn't have come together without their hard work and dedication. First, I'd like to thank Maria, my mentor and teacher for the past four years, and the chair of my thesis committee. Maria, you have pushed me to become the person I am today and with your help I've been able to achieve many things, but my thesis has been by far the largest hurdle I've jumped over. I truly couldn't have done this without you! Second, Tom for being a hard yet kind teacher, and pushing me to be a better writer in your class, and now a better scholar with this thesis. I am grateful for your willingness to work with me on this project. Third, Noha for hardly knowing me, but meeting with me to talk about your work, and agreeing to be on my committee. You were enthusiastic about my work even before it was truly an idea, and your guidance and suggestions have pushed me to be a better researcher. Finally, I'd like to thank my mom for helping me in any way she could throughout this process. Whether it was editing my papers or just talking me through a difficult problem, this process wouldn't have happened without your love and support. Thank you to all of you who made this project happen; while some might say this is my achievement, you all were cheerleaders, encouragers, and deserve credit as well! I am grateful for all of your guidance throughout this process! 


\section{CONTENTS}

$\begin{array}{lll}2 & \text { Page }\end{array}$

ACKNOWLEDGMENTS

$\begin{array}{ll}\text { CONTENTS } & \text { ii }\end{array}$

CHAPTER I: INTRODUCTION 1

CHAPTER II: PREVIOUS LITERATURE 4

Human Rights Treaty Compliance Literature $\quad 4$

Global Children's Rights Literature $\quad 9$

Children in Trouble with the Law 12

Gap in the Literature $\quad 14$

CHAPTER III: METHODOLOGY 16

$\begin{array}{ll}\text { The Reports } & 16\end{array}$

Sample 17

$\begin{array}{ll}\text { Analytic Process } & 18\end{array}$

$\begin{array}{ll}\text { Coding Process } & 19\end{array}$

CHAPTER IV: FINDINGS 22

Range of National Practices Regarding Children in Trouble with the Law 24

Patterns of National Practices Regarding Children in Trouble with the Law 27

Allowing the Institutional Corporal Punishment of Children in Prisons $\quad 27$

Continuing to Sentence Children with Adults 29

Not Addressing Children's Right to Remain in Contact with their Families $\quad 30$

Partially Outlawing Capital Punishment and Life Sentences without the

possibility of Release 31 
Setting the Age of Criminal Responsibility Lower than the Recommended Level

Holding Children in Pre-trial Detention for Longer Periods of Time

Future Research

APPENDIX B: FIGURE B-1: RANGE OF RIGHTS FOR CHILDREN IN TROUBLE

APPENDIX C: FIGURE C-1: PREVALENCE OF REPORTED COMPLIANCE OF 


\section{CHAPTER I: INTRODUCTION}

In the United States, there is a lot of research regarding children in trouble with the law. With this volume of research, scholars are able to generalize that children in trouble with the law are a vulnerable population. Many of the children who end up in the juvenile justice system in the United States are from broken homes with little support from parents or caregivers (Bartollas and Schmalleger 2013; Brunet, 2002; Howell, 2009; United Nations, Division for Social Policy and Development Youth 2011; Zalkind and Simon 2002; Zimring, Langer, and Tanenhaus 2015). These children may face emotional, physical, and sexual abuse in their home lives. Additionally, juveniles processed in the criminal justice system have a higher likelihood of having a diagnosed mental illness than those who are not processed in the criminal justice system putting them at greater risk for victimization during their lifetime (Bartollas and Schmalleger 2013; Howell 2009). The abuse and lack of support allow for the assumption that children who are in trouble with the law are victims before they are offenders. The upbringing of these young people leads to the increased risk of both victimization and criminality (Nofziger 2009). The neighborhoods that they live in as young children lead to the direct correlation between their offenses and victimization, and this correlation is cyclical (Nofziger 2009). This would imply that those who are faced with bad situations growing up are likely to put their children in similar situations perpetuating the abuses and victimizations to the next generation of children. These findings apply to the United States and shape policies and practices there. When we consider children in trouble with the law across the world, however, much less is known.

Despite there being little research on children in trouble with the law at a global level, such children have their rights spelled out in an international human rights treaty. The United Nations (UN) Convention on the Rights of the Child (CRC) lays out a vision to protect the rights 
of children in trouble with the law in many countries around the world. In Articles 37 and 40, the $\mathrm{CRC}$ recommends the following actions for children who break the law: they should not be given cruel punishments, should not be detained in jails or prisons with adult convicts, should not be denied access to their family, should not be sentenced to death or life without the possibility of parole, should have the right to an attorney or legal counsel, should have a minimum age of criminal responsibility set by the government, and should have the right to a fair and speedy trial (United Nations 1989). These rights and protections in addition to other UN Provisions (including the Beijing Rules, the Riyadh Guidelines, the Havana Rules, and the Committee's General Comment No. 10 from 2007) provide a roadmap for governments who wish to ensure that children who are in conflict with the law are treated with dignity and respect.

Since the creation of the CRC in 1989, 195 countries have ratified the document making it the most widely ratified human rights document. Compliance with the $\mathrm{CRC}$ requires regular reporting by member countries, and my research examines countries' reported compliance with the 2 articles of the CRC which pertain to children in trouble with the law: Articles 37 and 40. It also includes the reports from non-governmental organizations (NGOs), and the Committee. The NGO reports act as a check on the country reports either supporting or contradicting the information in them. These reports are crucial to ensuring the validity and reliability of the country and Committee reports. While children in trouble with the law are heavily researched in the United States, almost no research gives a truly global empirical picture of practices pertaining to these children. This research project is designed to use the best available data to discern the reported situation of children in trouble with the law on a global scale. While these reports are the best available data, there are some limitations to these reports. Each country has its own agenda and the potential to report incomplete or misleading information. It would be 
impractical, expensive, and highly time consuming to go to every applicable country to validate what is being written about its compliance. Additionally, researchers might not be given access to each of the applicable countries around the world. Thus, we are left with an approximate measure of compliance as reported by the country themselves. Despite the potential for inaccuracy in the country reports, we have no better data that can give us a sense of global comparison with regards to children in trouble with the law. This research has the potential to lay the groundwork for future research that will explain the global variation in implementation/compliance. This research examines the question: "What are the global range and patterns of national practices regarding children in trouble with the law?" 


\section{CHAPTER II: PREVIOUS LITERATURE}

There are three avenues of research that influence my discussion of children in trouble with the law and the CRC: human rights treaty compliance, global children's rights, and research specific to Articles 37 and 40 of the CRC. The latter two lines of research, more specific to children's rights, argue that more empirical work needs to be done on the global level to allow for further examination of compliance with the $\mathrm{CRC}$, and drawing on the human rights treaty compliance literature allows for a more general understanding of factors that contribute to global variation in the implementation of human rights treaties. My research seeks to study children in trouble with the law from a globally comparative perspective in an effort to identify the global variation in rights of children in trouble with the law, and lay a foundation for future research that could explore reasons for the variation. Possible explanatory factors include countries' levels of democracy, region, wealth, and levels of commitment to different categories of children's rights.

\section{HUMAN RIGHTS TREATY COMPLIANCE LITERATURE}

The human rights treaty compliance literature offers theoretical insight into why there is variation in the implementation and compliance with human rights documents. There is a lot of research on human rights treaty compliance, but Hafner-Burton (2012) and Cardenas (2007) identify the most prominent explanations and theories of compliance which to help to inform the discussion of why there is variation in implementation or compliance with human rights documents. While this line of work is theoretically relevant to the current research, there is little in this line of work that discusses the CRC.

Authors such as Cardenas (2007) and Hafner-Burton (2012) further our understanding of the theoretical backings to research in their reviews of the human rights compliance literature. 
Both Cardenas (2007) and Hafner-Burton (2012) express that there are several ways that authors explain compliance: type of government (democratic or autocratic), desire to be seen positively in the global community, the level of agreement with treaty, and regional location. Cardenas (2007) outlines the various explanatory factors as international/regional, domestic, domesticinternational interaction, and cross-cutting pressures; however, she notes that while these are distinct categories, they are mutually reinforcing. The author reveals that government and bureaucratic politics along with regime type and civil society all influence compliance with international human rights on a domestic level. Additionally, she reveals that the factors she outlines are the foundation for further research and that research should use these existing factors to explain how they understand human rights norms violations.

Furthering this line of work, Hafner-Burton (2012) explains that authoritarian governments are less likely to ratify and comply with human rights documents, and if they do ratify the document, they are far less likely to comply. Likewise, there are regional trends in compliance with human rights documents; countries in the same region are more likely to be at the same level of compliance. While neither Cardenas (2007) nor Hafner-Burton (2012) mention children's rights as an explicit example within their discussions of the human rights treaty compliance literature, it is clear through the previous work on children's rights that these theories are relevant to explaining the variation present in the $\mathrm{CRC}$ as well.

Looking at more empirical evidence of human rights treaty compliance, Powell and Staton (2009); De Mesquita, Downs, Smith, and Cherif (2005); Landman and Larizza (2009); Hawkins (2004); Goodliffe, Hawkins, Horne, and Nielsen (2012); and Nielsen and Simmons (2015) all discuss aspects of the aforementioned theories of human rights compliance. Focusing on the conventions protecting from ill-treatment and cruelty, these authors have been able to 
discern that even though there are many explanations of compliance, no single explanation alone thoroughly explains compliance or non-compliance.

Powell and Staton (2009) used domestic judiciaries as an influence on the ratification of human rights treaties. The authors use the Convention Against Torture (CAT) and data from 1987-2000 to test two hypotheses focusing on how judicial effectiveness impacts the probability of ratification and engagement in human rights treaties and practices. Their first hypothesis posited that judicial effectiveness would increase the probability of ratification and engagement in human rights, and the second hypothesis was the inverse of the first (Powell and Staton 2009). They found support for their first hypothesis, and did not find significant support for their second hypothesis. Their findings suggest that effective domestic judicial systems help to prevent human rights violations.

In another study, De Mesquita, Downs, Smith, and Cherif (2005) argued that there are many different factors within democracy that further the discussion of human rights violations. The authors tested three hypotheses regarding how level of democracy impacts human rights outcomes. First, they hypothesized that level of democracy would not impact human rights outcomes. Similarly, they hypothesized that as democracy level increases, it doesn't necessarily mean that there will be improved human rights in a country. Finally, the authors hypothesized that level of democracy would predict human rights outcomes (De Mesquita et al. 2005). The authors drew on data from Polity IV, and used indicators to create a scale of democracyautocracy. De Mesquita et al. (2005) concluded that participation and competition within the government, for example in a multiparty system, is significant in reducing human rights violations; improving the level of democracy, up to a full democracy, didn't impact the level of rights protections in a state; and accountability in full democracies was the crucial factor that 
reduces human rights violations. These finding reveal a more complicated picture than the original theory suggests.

In an effort to further the knowledge about state compliance with human rights, Landman and Larizza (2009) discussed the relationship between inequality in a country and the protection of rights. They used data from 162 countries between the years 1980-2004 from the U.S. State Department, Amnesty International, and Human Rights Watch. They looked at personal integrity rights and land and income inequality. They found support for their argument that inequality helps predict the rights violations of a country. Most compelling was income inequality as a predictor of personal integrity rights violations. This would suggest that it isn't the democratization of a country, but the wealth that would predict the human rights violations.

The second set of empirical research based on human rights treaty compliance is linked to country persuasion. There are a few competing studies that suggest that persuasion is a factor when states are considering ratifying a human rights treaty. Hawkins (2004) conducted a study that suggested that power, interests, and content of arguments were all relevant to understanding why states ratify human rights treaties. Looking at the Convention Against Torture, Hawkins (2004) was able to show support for the persuasion model of ratifying human rights treaties by looking at countries' initial responses to the Convention Against Torture (which was widely opposed to) and the subsequent approval of the Convention within a relatively short time frame. In doing this analysis, Hawkins was able to show that there were a series of arguments that states for and against the Convention used as a way to persuade other states. States that were opposed to the Convention argued that the universal jurisdiction proposed within the Convention Against Torture as a means of enforcement violated sovereignty; the provisions within the Convention wouldn't actually end torture; and innocent people would get hurt through the provisions within 
the Convention by wrongful accusations. These three arguments were countered by states who were proponents of the Convention by showing that no state could reasonably argue in favor of torture; universal jurisdiction was already being utilized in other treaties developed in recent history; and without a universal jurisdiction, a state that was using torture as a means wouldn't prosecute themselves for crimes. Each of these approaches was hard to argue against; however, as proponents argued their case, and more states were persuaded to accept the terms of the treaty, Hawkins reports regional chain reactions of states agreeing to the terms and not wanting to stand in the way of the document.

Another study in this line of thinking was done by Goodliffe, Hawkins, Horne, and Nielsen (2012). This research looked at states joining the International Criminal Court (ICC) as a mean of enforcing human rights. Goodliffe et al. (2012:133) argued that dependence networks, or "the set of partners on whom a given actor relies for exchange," reveal a pattern for accession to the ICC. Authors conducted a historical analysis that shows when countries committed to the ICC (between 1998 when the ICC was implemented, and 2004). They found that dependence networks had a large influence on a country signing or ratifying the ICC.

To contrast the research suggesting that persuasion is a key factor in a country's decision to ratify a treaty, Nielsen and Simmons (2015) discussed the influence of rewards for ratification. They looked at material and immaterial benefits of signing human rights documents to see if there was any evidence to suggest that expectation of increased benefits, material or immaterial, affect the signing a human rights treaty. The authors looked at the International Covenant on Civil and Political Rights (ICCPR), the First Optional Protocol to the International Covenant on Civil and Political Rights (OP 1), the Convention Against Torture (CAT), and the optional 22nd Article of the Convention Against Torture (Art. 22). The authors suggest that the findings of this 
study should extend to other conventions, such as the CRC or the Disabilities Conventions. For each case they looked at an 11 year period of time, 5 years before ratification and 6 years during and after ratification to assess whether there were any changes post-ratification. The authors found no support for the reward theory, and there was no evidence to suggest that benefits increased post-ratification, in cases of both material and immaterial rewards. Each of these studies addresses a slightly different issue when it comes to the theory that countries persuade other states to ratify human rights treaties. While there is evidence that there is persuasion in the initial signing and ratification, there is no support for benefits as a result of ratification of a treaty.

There are many studies done on human rights compliance with various human rights treaties, but there is agreement in the literature that there is no single explanation for why a country would ratify and then not comply with a human rights treaty. Studies of compliance have been particularly prevalent over the last thirty years, but there is still a lack of globally comparative work. Many studies highlight one specific area, region, or state. Of the few globally representative studies, findings suggest that there is a range of implementation despite ratification. There is also very little knowledge in this area about children's rights. These deficits lead to the discussion of children's rights more narrowly. With the CRC being the most widely ratified human rights document, it allows for further exploration of why there is mixed compliance with human rights documents.

\section{GLOBAL CHILDREN'S RIGHTS LITERATURE}

The research on global children's rights identifies the need for more exploratory research on children's rights (Gran 2010; Polonko Lombardo, and Bolling 2016). This line of work establishes that there is very little globally comparative work on children's rights and in order to 
move the field forward, more work has to explore the rights of children, and then use the foundational research to try to explain the variation in implementation and reported compliance (Gran 2010; Polonko et al. 2016). Two pivotal studies (Gran 2010; Polonko et al. 2016) that greatly influence my research are examples of foundational research that show the variation in the current state of children's rights, and call for future research to further explore the reasons for that variation.

Polonko et al.'s (2016) study discusses the reporting practices of countries around the world to the Committee on the Rights of the Child and explains the implementation differences across countries in the area of law reform. The authors quantitatively compared 179 country reports, NGO reports to The Committee, and Committee responses from 1989 to 2005, and looked to explain variation based on different kinds of rights: children's welfare rights (such as the right to good health care, the right to free primary education, and protections against child mortality), transitional rights (such as protections against capital punishment for crimes and child marriage), and equality rights (such as protections from abuse and neglect, mental and physical violence, and injury). They explain that both transitional rights and welfare rights were mentioned in the context of legislative changes more often than equality rights, but only welfare rights were implemented most frequently. Additionally, they found children's equal rights were only reported as implemented in about one-third of the countries that have ratified the CRC. The authors argue that children's welfare or protection rights are the most likely to be implemented, and children's equality rights are the least likely to be implemented; this leaves transitional rights in the middle. While the authors were able to discuss equality rights and welfare rights as the two extremes, they don't fully address transitional rights, such as those affecting children in trouble with the law. This study is an important step forward and offers the 'type of right' (welfare, 
transitional, or equality) as an explanatory factor influencing implementation. Rights of children in trouble with the law fall under the transitional right category, and this research helps to show that they are less likely to be implemented than are welfare rights. Given this, it is clear that more work needs to be done to understand the transitional rights of children. Polonko et al. (2016) also called for more research laying the foundation of variation in children's rights in order to fully understand the complexities of implementation of the CRC.

In a similar article, Gran (2010) links the human rights treaty compliance literature to the children's rights literature through his discussion of the "Children's Rights Index." This index was developed by Gran to show the level of children's rights in countries around the world. He draws on two specific rights for each of the categories of children's political, civil, social, and economic rights in 190 countries using the United States Department of State's Country Reports on Human Rights Practices. Gran (2010: 5-6) uses the two civil rights of "freedom of conscience" and "freedom from imprisonment with adults;" political rights of " the right to vote" and "the right to assemble;" social rights of "the right to education" and "the right to health care;" and economic rights of "freedom from economic exploitation" and "freedom from hazardous work." Each of these rights, with the exception of the right to vote, are drawn from the CRC. Using these indicators of children's rights, Gran (2010) found that no country in the analysis was implementing all 8 rights to children, and no country was denying all 8 rights to children, but was able to show that implementation varied by region, level of democracy, and the wealth of countries. These findings along with the work of Hafner-Burton (2012) and Polonko et al. (2016) give four categories for understanding the variation in children's rights implementation: wealth of a country, level of democracy in a country, region the country is in, and kind of rights being evaluated. 


\section{CHILDREN IN TROUBLE WITH THE LAW}

The literature on global juvenile justice makes clear that the $\mathrm{CRC}$ is the only internationally enforced children's rights document and is the foundation for understanding global juvenile justice (Kilkelly 2008; Zalkind \& Simon 2002; Zimring et al. 2015). There are a few case studies that look at how specific countries use the CRC to help children in trouble with the law (Ame 2011; Lynch 2008; Storgaard 2004), but no globally comparative studies that establish a foundation for the rights of children in trouble with the law. Individual country and regional studies have brought some sense of compliance with the $\mathrm{CRC}$ and the efficacy of that compliance. Here I discuss several examples.

Ame (2011) reports that Ghana, while making some strides, is not fully implementing the CRC in regards to children in trouble with the law. While Ghana's parliament passed the Juvenile Justice Act in 2003, there is a gap between what is written on paper, and what is actually happening in the country. While this country is faced with a variety of other basic children's rights issues, Ame (2011) was only focused on how the country is implementing the Juvenile Justice Act. He determined that this act is in compliance with the CRC's articles pertaining to juvenile justice, but it lacks power because of the unsupportive societal perception of children's matters and stigma against those who are in trouble with the law.

A different situation was reported by Storgaard (2004). She points to Scandinavian countries' legal systems, and the protections children in these countries have. She evaluates that while these countries have a very high age of criminal responsibility (the minimum age that a person can be held accountable in court), their laws don't prohibit juvenile offenders aged 15 to 17 from being held in the same facilities as adult offenders. To compare, in the United States the age of criminal responsibility is set anywhere between six- and fourteen-years-old; because each 
state has the ability to choose the age of criminal responsibility, children as young as six-yearsold can be tried for a crime in certain states (Bartollas and Schmalleger 2013). Storgaard (2004) continues by explaining that the Scandinavian countries still have mixed implementation of the CRC's protocols despite having signed the CRC in the early 1990's. This research is comparing the Scandinavian countries to one another, but these comparisons, while helpful, don't address the juvenile justice system on a global scale. These two articles show the differences in practice that are apparent in each of these very different areas of the world.

Furthering this discussion, Lynch (2008) discussed children's justice in New Zealand. The author looked at the New Zealand juvenile justice system with a particular interest in addressing the implementation of the Convention on the Rights of the Child. She described that while the country is doing a lot of good things for children in trouble with the law, it is also neglecting some areas, much like the previous studies have indicated. She also revealed that the restorative justice model, a system of community restoration that allows mediation between the victim and offender, might impact children's legal rights as well given that it would take away the child's rights to privacy (Article 16 of the CRC). Children in trouble with the law are given the right to privacy through sealed records (records that are not available to the public) and closed trials (trials that are not open to the public), but by incorporating mediation and community involvement in the rehabilitation of the young person, they take away the ability to keep the child's status confidential within the court system. While community based approaches have helped some communities accept and reestablish a relationship with offenders, it could be detrimental to a juvenile offender. This reveals another avenue of concerns for children's rights around the world as new models of mediation might threaten children's rights. 
These studies enable a more nuanced understanding of difficulties countries face in complying with Articles 37 and 40. They are the only studies specifically looking at articles 37 and 40 of the CRC. These articles are focused on single countries, but reveal the trouble that these countries have faced implementing articles 37 and 40 of the CRC. A notable absence in the literature, though, is a global approach to country practices regarding children in trouble with the law.

Finally, Kilkelly (2008) established the importance of Articles 37 and 40, the articles that pertain to children in trouble with the law. The author first addresses the weaknesses in Articles 37 and 40 of the CRC. She explained that these articles, among other globally recognized laws, are "too vague on detention as a last resort; too weak on the age of criminal responsibility and they are incomplete on the trial process, sentencing and serious crime" (Kilkelly 2008:191). However, she also explained that these are among the few documents that are globally recognized and that give children and youth protection when they break the law. While many post-industrial countries have given children the rights guaranteed through Articles 37 and 40 of the $\mathrm{CRC}$, these protections and rights are crucial for countries that are emerging from war, undergoing industrialization and modernization, or looking to modify their penal codes and system. Additionally, while these countries might guarantee these rights on paper by signing the convention, the reality of what any country has been able to do for children in conflict with the law might not match the parameters set by the CRC (Goldson and Kilkelly 2013; Kilkelly 2008). This article further illustrates the need for additional research on Articles 37 and 40 of the CRC. GAP IN THE LITERATURE

The preliminary research suggests a lack of global comparison. With the exception of two studies (Gran 2010; Polonko, Lombardo, and Bolling 2016), the present literature makes fewer 
comparisons across countries, such as Storgaard's (2004) research looking at just Scandinavian countries, or makes no comparisons and just looks at one country (Ame 2011; Lynch 2008). These case studies also fail to utilize the country reports, NGO reports, and The Committee's responses to these reports. More exploratory work needs to be done addressing transitional rights, as pointed out by Polonko et al (2016), and utilizing the human rights compliance theories. The literature, while acknowledging a problem with the current system, doesn't explore the scope of how implementation varies around the world, nor does it draw on the human rights compliance literature which offers insight into why variation occurs in implementation and compliance. This study contributes to filling that gap by qualitatively comparing countries' reported compliance with the $\mathrm{CRC}$ around the world and exploring the variation of implementation around the world. 


\section{CHAPTER III: METHODOLOGY}

The CRC is important and relevant to children in trouble with the law around the world which is why I used CRC data to answer the question: "What are the global range and patterns of national practices regarding children in trouble with the law?" The specific method I used was qualitative content analysis of the each of the country reports, the NGO supplemental reports, and the responses of The Committee to each of these reports from the years 2005-2015 (in some of the later years, the concluding responses for the country report came from 2016 or 2017) which helped to identify which countries are implementing rights and protections to children who are in trouble with the law. This study aimed at analyzing the documents submitted to the Committee on the Rights of the Child by both the country itself, the NGOs that have submitted supplementary reports on that country, and the Committee's responses to better understand the range and extent of implementation of the $\mathrm{CRC}$ in the area of children in trouble with the law.

\section{THE REPORTS}

Each of the signatory countries of the $\mathrm{CRC}$ are expected to submit a country report, or an update on how they are implementing the articles of the CRC into their country, two years after the initial signing of the document and every five years after that. These reports are submitted by the countries to the Committee, so that the Committee can track the progress each country is making. The NGO reports are also submitted to the Committee to supplement the country report. NGOs may submit their own reports, and through this mechanism offer and alternative view of practices related to children's rights in countries on which they focus. They offer more information on the situation of specific rights to children or more information on the situation of children's rights in general. Once these reports are submitted, the Committee responds to the countries through written feedback on the country report. I used all of the country reports, the 
written feedback from the Committee, and NGO supplemental reports for Articles 37 and 40 from the years 2005 to 2015 as my data. All of the reports in this analysis are available online in English and can be accessed by the public.

\section{SAMPLE}

There are 194 countries that signed the CRC prior to 2015, and two out of fifty-four articles of the CRC that are relevant to this study. This study includes 169 countries as data because these were the only countries that submitted reports during the time frame of 2005-2015. The other 25 countries that have signed the CRC did not have a report submitted for the time frame included in this analysis with the exception of one country that didn't have enough information on articles 37 and 40 in any of the reports (see Table A-1 for full list of countries). There were a grand total of 476 reports included in this analysis (169 country reports or 636 pages, 168 Committee responses or 336 pages, and 139 NGO Reports or 278 pages). The number of pages that were relevant within each report ranged from 2-20 pages for a grand total of 1,250 pages. In order to answer my research question, it was important to identify comparable data so that the range and patterns of practice could be discerned in all of the countries. NGOs were an important piece of my analysis because they offered a check on what the other documents were addressing. There were a total of 341 NGO reports that gave information on only 89 countries of the 169 included in this study; however, 202 of those reports didn't contain information relevant to the state of juvenile justice and were not relevant to this study. Of the 139 NGO reports, there were 133 reports that confirmed the information in the country and Committee reports. Only 6 reports for 5 countries contradicted the information in the country and Committee reports (see table A-2). 


\section{ANALYTIC PROCESS}

Qualitative content analysis of these documents is the best method for this project because it allowed me to discover patterns of juvenile justice around the world. By using CRC documents, this project was able to establish how compliant each country was to the provisions outlined by the CRC. It allowed for an assessment of reported compliance without being intrusive and impractical (Hesse-Biber and Leavy 2011). It would be intrusive to ask juveniles, who are a protected population to study, what their experiences in the justice system are, and it is impractical to fly around the world to talk to many individuals in English or with a translator about their experiences in the juvenile justice system of all 194 countries. Analyzing these documents facilitates a discussion of what is being done by countries to implement the rights and protections of children who are in trouble with the law.

Most of the country reports and Committee responses were organized in the same order which made finding the exact sections that discussed articles 37 and 40 fairly easy to find. There were a few exceptions to the organization patterns of the country reports and Committee responses which included the 2011 report for India, and countries that had independent states or provinces such as Canada, the United Kingdom, Ireland, Australia, and the Netherlands. Most reports gave a table of contents and the page number where these issues were discussed. For reports that didn't use this standard format, I used the "find text" function and searched for: “article 37," "art. 37," "torture or other cruel, inhuman or degrading treatment or punishment," “article 40," "art. 40," "administration of juvenile justice," "children in trouble with the law," or "children in conflict with the law." These search terms were used most frequently for the NGO reports because they are not organized in the same way as the country reports and the Committee 
responses. In cases where the "find text" function didn't work, I read through the whole document to see if there was any relevant information on children in trouble with the law.

\section{CODING PROCESS}

Article 37 of the CRC gives the following 4 protections: children who break the law should not be given cruel punishments, they should not be detained in jails or prisons with adult convicts, they should not be denied access to their family, and they should not be sentenced to death or life without the possibility of parole (United Nations 1989). Article 40 of the CRC gives children 3 rights: the right to an attorney or legal counsel, a minimum age of criminal responsibility set by the government, and the right to a fair and speedy trial (United Nations 1989). When looked at together Articles 37 and 40 give seven basic due process rights to children around the world. Given the research questions of this study, I used focused analytic coding (Lofland and Lofland 1995). Through this coding process I looked for specific instances that indicate the level of reported compliance (divided into high, medium, low; see figure B-1) with the 7 rights and protections guaranteed through articles 37 and 40 . Countries used phrases indicating their compliance, such as "Although the right to legal representation is enshrined in the Constitution, Zambia wishes to state that it cannot guarantee the same to children" (Zambia Country Report page 45).Countries, NGOs, and the Committee also referenced the constitution, statutes, codes, decrees, case law, and discussed particular situations of children in trouble with the law which indicated the country's level of compliance with the CRC. Each of these references helped me assess how the country was implementing the 7 rights guaranteed in the CRC. Further, I counted the number of rights addressed in each of the country, NGO, and Committee reports. Both rights that were complied with or positively addressed rights and rights that weren't complied with or negatively addressed were counted; therefore, countries had two 
tallies. When a right was positively addressed in a report with the country showing compliance with that right, I counted that as one right in compliance. In cases where rights were discussed negatively, or countries discussed their lack of ability to comply with a right, I counted that as one right in noncompliance. Circumstances of discussions that omitted rights were counted zero and in their own category which didn't impact either the rights in compliance or noncompliance totals. Countries that were in compliance with more rights than omitted rights or rights not being complied with fell in the high-medium category. Countries that were fairly evenly split between rights complied with and rights not complied with and had one or two omissions, fell in the midmedium category. Countries that had more rights not complied with or rights omitted than rights complied with fell in the low-medium category. In the few cases where an NGO report contradicted the information present in the country report and concluding observations report, I considered what was being contradicted from the other information present. The contradictory information from NGO reports and Committee responses took precedence over country report information.

To illustrate this with an example, Azerbaijan's 2011 NGO report indicates that children are not separated from adults in prisons and they are tried as adults with long pretrial detentions. Azerbaijan's country report identified that it was against the law for children to be held with adults in prisons and information about the length of the trial and the court the trial was held in was omitted from the report altogether. In this instance, I recoded the zeros from omitted information to one right in noncompliance. In regards to children being held in prisons with adults, the Committee noted that they were concerned about the situation of children in adult prisons which then changed the initial code of one "right being complied with" to "right not being complied with." Azerbaijan still falls in the mid-medium category despite the NGO report 
contradicting the preliminary country report. Each country revealed a different story about reported compliance; subsequently, this process revealed the variation in implementation of the CRC's articles. 


\section{CHAPTER IV: FINDINGS}

Through looking for "the global range and patterns of national practices regarding children in trouble with the law," I've found several trends and patterns that are present throughout the world when looking at the CRC country reports, NGO supplemental reports, and Committee responses to these reports. This section will be broken into 3 subsections regarding the range of national practices regarding children in trouble with the law, the patterns of national practices regarding children in trouble with the law, and then the prevalence of reported compliance across the 7 rights. This analysis helped to show what the reported state of juvenile justice is like globally, and the variations in how children's human rights are reportedly fulfilled in countries around the world.

To preface the discussion of findings, it is important to recognize that many countries were able to admit both their strengths and weaknesses for each of the various rights, and these admissions were often supported through the NGO reports and the Committee responses. There were many cases where country reports would indicate a law or decree that had been put in place, but then recognized that the law or decree was not being fully implemented in practice. One such case was from Mali's 2006 report in reference to keeping juveniles in special juvenile quarters when detained; the government admitted: "These provisions are not strictly enforced for several reasons, including difficulty of contacting parents or guardians and the lack of premises for minors" (page 136 of the State Party Report). This recognition of the practices of the country not following the laws, helps validate the information that countries are reporting.

Denmark, in its 2010 report, explained to the Committee that children under the age of 15 cannot be punished, but then the report goes on to explain, 
The Administration of Justice Act give[s] the police the possibility to detain children under the age of 15 who are suspected of criminal conduct if the general requirements for arrest are met and if the purpose of the detention cannot be obtained in less interventive ways [...] [Intervention] may as a main rule also be used against children under the age of criminal responsibility, for example interception of communications, surveillance, data reading, bodily interference, searches, seizure and disclosure of documents. (86-87) These statements contradict the purpose of a minimum age of criminal responsibility as police intervention exposes children to the criminal justice system.

One of the more surprising admissions was of Singapore, in their 2010 report, with regards to corporal punishment practices. The country explains:

For such serious offences, juveniles may be subjected to judicial caning. Under Singapore's laws, a juvenile offender will be caned with a light rattan instead of the usual rattan used for adults. Females are not liable to caning under Section 231 of the Criminal Procedure Code (CPC). In the period of 2003 to June 2007, 76 juvenile offenders were sentenced to judicial caning with a light Cane. (44)

Further, Singapore explains: "Singapore is of the view that the regulated use of corporal punishment is an acceptable mode of discipline, and does not constitute violence against children and made [a modification to] the declaration on Article 37 in this regard" (44). This discussion reveals that the country is admitting to and explaining its use of corporal punishment against children. This was a surprising admission and very different from countries that omitted discussion on corporal punishment of children in various ways in an effort to hide the practices.

There were many more cases of countries that would simply omit the practice of their countries and just convey what laws were currently in place. When this happened, NGO reports 
often revealed that these laws weren't always followed in practice, or the Committee brought this issue to light in their reply to the country report. However, there were several countries that admitted on their own where the shortcomings of their laws were, and where they thought more attention needed to be paid in the near future. Vietnam in their 2011 report, remarked that "Viet Nam has also focused on improving awareness and the capacity of workers working on children in conflict with the law through developing documents and organizing training on child friendly investigations for key officers of the investigation police forces nationwide" (86) in an effort to reduce the abuses that take place in the juvenile justice system.

RANGE OF NATIONAL PRACTICES REGARDING CHILDREN IN TROUBLE WITH THE LAW

Of the 169 countries that are included in this study, no country was fully implementing all 7 rights, nor was there a country that was disregarding all 7 rights, which implies that all countries in this study would fall in a medium category (see Figure B-1). In many cases, countries ignored or overlooked some of the 7 rights and did not include them in their discussions at all. These omissions became more prevalent when the Committee would reiterate previous recommendations that they had made in the previous reporting period. Given this, each of the 169 countries were sorted into three categories: high-medium, mid-medium, and lowmedium.

There were 19 out of 169 countries that were in the high-medium category (Table A-3). These countries were implementing 5-6 of the 7 rights that should be guaranteed to children, and that information was confirmed by the NGO report if there was one. While they weren't implementing all 7 of the rights, a majority of the rights were being implemented. To illustrate this point, the reports on Egypt revealed that in most circumstances, there was legislation in 
place to protect the rights of children in trouble with the law, but as was the case for separate detention facilities, in some cases children were still being detained with adult convicts. The country report had been submitted to the Committee in 2010 , which is relatively recently, but as we can see through this example of one protection, children's rights aren't always fully implemented.

In an even more recent report for South Africa (submitted to the Committee in 2015), it was revealed that children there aren't yet granted an internationally acceptable age of criminal responsibility. In South Africa, children as young as 10 years old can be held criminally responsible, and the Committee recommends setting the age of criminal responsibility to at least 14 years. Both of these examples are emblematic of the larger group of countries that would fall into this category (see Table A-3), and show that both separation of juveniles from adults and the age of criminal responsibility being set too low were common rights that even the most compliant countries, when compared with the others, did not fully implement.

The majority of countries (130 out of 169) fall in the mid-medium category (see Table A4). These countries were implementing 3-4 of 7 rights, and had the Committee recommending several improvements to the country's current juvenile justice system. In many cases these countries omitted many details about the actual practices, and left several rights not mentioned.

To represent this point, the reports for Senegal showed that children didn't have the legislative protection against cruel, inhuman, and degrading punishment or treatment; they were detained in settings with adults; and the age of criminal responsibility is 13 . These were the only rights explicitly discussed within the country report. Senegal was reporting to the Committee in 2006 when the Committee on the Rights of the Child was recommending an age of criminal responsibility of 12 or higher. Therefore, this example underscores the fact that the country had 
an appropriate age of criminal responsibility, but they weren't separating children from adult convicts, or implementing laws that prohibited corporal punishment.

Likewise, Cuba (reported to the Committee in 2010), omitted details about some rights while discussing other rights. In this case, Cuba only thoroughly discussed the lack of protecting children from adult convicts in detention and outlawing the death penalty for children. This country report showed a similar level of reported compliance to Senegal, but mentioned different rights for children. The reports for each of these countries represent the mid-medium range of practices through the way they discussed only a few rights and they weren't showing the positive implementation practices for the rights they discussed in all cases.

Twenty-four out of 169 countries were coded into the final category, low-medium. These countries were implementing 1-2 of the 7 rights (see Table A-5). Very few rights were discussed overall, and when rights were discussed, the discussion consisted of which rights weren't available to children. The majority of these countries were still implementing, had allegations of, or didn't outlaw specifically corporal punishment in prisons, but this wasn't the only right that wasn't being complied with in many countries within this category.

To illustrate this point, Benin reported to the Committee in 2005, and included in its report that there was no minimum age of criminal responsibility, children had the possibility of being sentenced to death or life imprisonment, the right to maintain contact with one's family was not enforced, and they didn't separate juvenile and adult offenders. The reports didn't discuss the other rights.

A more recent example comes from Iraq, which reported to the Committee in 2014. Iraq's reports indicated that children were subjected to corporal punishment in the penal setting, children could receive the death penalty, and children as young as 9 years old could be processed 
in the criminal justice system. These two examples help to show that the countries in this category often don't discuss positive implementation of the rights that are supposed to be in place for children in trouble with the law.

PATTERNS OF NATIONAL PRACTICES REGARDING CHILDREN IN TROUBLE WITH THE LAW

The analysis of the range of practices revealed that there was variation in the overall rights that countries were implementing (from high-medium to low-medium), and consistent patterns within the three reports. There were many patterns in the practices of countries including: allowing the institutional corporal punishment of children in prisons; continuing to sentence children with adults; not addressing children's right to remain in contact with their families; outlawing capital punishment, but not life sentences without the possibility of release; lack of adequate legal aid for children; setting the age of criminal responsibility lower than the recommended level; holding children in pre-trial detention for long periods of time. Each of these patterns was seen in several reports and can be illustrated through examples.

\section{Allowing the Institutional Corporal Punishment of Children in Prisons}

There were 56 countries that recognized and justified institutional corporal punishment of children in prisons. Not only is this practice openly recognized by countries, they admit that it is a gendered practice in that only boys could receive this form of punishment, as seen in the Singapore example. Generally, when this occurred, the number of lashes or whips was written in the law, the physical health of the child was considered, and the punishment was supervised by a parent or third party. Saint Vincent and the Grenadines, in their 2013 report, reveals that:

[The law] specifies the maximum number of strokes that may be administered to the juvenile offender and requires the court to specify the number of strokes that may be 
administered to the juvenile offender and requires the court to specify the number within the maximum of twelve that must be administered [...] caning shall be administered on the buttocks, with a light rod or cane of birch or tamarind or twig (32)

The legalized and regulated caning of children is not only recognized in Saint Vincent and the Grenadines, but in several other countries as well.

While some countries admitted to their physical corporal punishment practices, other countries alluded to punishing children in more subtle ways, such as solitary confinement or using police interrogation tactics. These practices were more about the mental harm done to children in some cases rather than the physical abuse of children in the prison system. These practices were also less pronounced in the country reports and were more likely to be revealed in the Committee responses. The Committee's response to Armenia's 2011 report discussed how the Committee was concerned that "children may be subjected to 5-10 days of solitary confinement as a punishment" (12) and the Committee recommended that Armenia "take immediate measures to ban solitary confinement of children which amounts to inhuman treatment" (13).

Reports as late as 2017 still discuss the inadequate treatment of children in penal institutions. The Committee's response in 2017 to Saint Vincent and the Grenadines' 2013 report revealed that the practices discussed above are still occurring in the country. The Committee is concerned that "[the law] has not been amended and allows the caning of children who have been found guilty of a crime" (12). Currently, there are no provisions in the country that prevent ill-treatment of children. This is the most recent report that was included in the study and there are still concerns about children being caned. 


\section{Continuing to Sentence Children with Adults}

Children around the world are held with adult convicts. Some countries express that there are not enough resources, human and financial, to staff and run juvenile prisons throughout their country, that there aren't enough juveniles in trouble with the law receiving custodial sentences to build a separate facility, or that it is a temporary housing while still in police custody. Ghana explains in its 2014 report that despite being against the law, children are still held in detention facilities with adults: "The laws of Ghana do not allow the detention of children in adult detention facilities, but a number of juveniles were found held in police stations (pre-trial detention). Children are likely to be detained in adult detention facilities when they increase in age" (64). Ghana's report reveals the disconnect between law and practice, but also the inability of the country to enforce the separation of juveniles and adults.

Norway's 2009 report reveals a different story in that there are too few juvenile offenders for them to have their own facility. The report states:

Due to the low number of children under the age of 18 years, who at any time find themselves in Norwegian prisons, it will result in virtually complete isolation if children and young people should be kept separated from the adult inmates. Such a solution will, according to Norway's view, not be in the best interest of the child. The young inmates shall nevertheless have special follow-up by the prison staff to prevent harmful effects of the imprisonment. (115)

This section reveals that separating children and adults leads to solitary confinement of the juvenile which isn't good for the juvenile's development and mental health.

Another problem is when there is an age based distinction. Several (11 out of 169) countries will separate children under 15 to 17 from adults, but put children who are 15 to 17 in 
adult prisons. Ghana's 2014 report indicated this idea, and the Committee's response to Yemen's 2012 report also revealed that 15-18 year olds are held with adult prisoners despite the fact that Yemen's country report expressed that their right to separate facilities was being ensured. Yemen's report states: "Where necessary in the case of a serious offence, a juvenile over 15 years of age may be held at a police station for a period of not more than 24 hours and in a place that precludes him from mixing with other detainees who are older than him" (107). While the Committee's response indicates that it is concerned at: "[t]he situation of children in conflict with the law between 15 and 18 years, who are treated as adults by the justice system and held in prisons for adults" (18). In the above cases and the other cases not mentioned here, it is imperative to recognize that children and youth are being held with adult prisoners and that is not in the best interest of the child.

Not Addressing Children's Right to Remain in Contact with their Families

This right of children was the least discussed in all of the reports (only discussed in the reports of 19 countries). There were only three instances that country reports, NGO reports, or Committee responses indicated that this right was not being addressed adequately in law or practice. Benin's 2005 report indicated that this right was not enforced, Georgia's 2007 report indicated that juveniles had limited access to visitors, which would include family, and Kazakhstan's 2012 report revealed that by putting children in detention centers, they have limited access to their parents. Only a handful of other instances (16 instances) in the various reports indicated that there were laws or practices that maintained children's contact with their family. One such instance where it was discussed, Honduras' 2014 report, says: "The code on Children and the Family was amended so as to ensure that in most cases, juvenile offenders are not separated from their family and social environment" (122). This is one of only a few other 
countries that mentioned this right explicitly and showed that family connections were a part of the juvenile's experiences in the justice system.

Partially Outlawing Capital Punishment, and Life Sentences without the Possibility of Release

Forty-six countries have complied with the provision to protect children from capital punishment and life sentences without the possibility of release. However, 12 out of 169 countries have shown that they are not incompliance with this provision of the CRC by outlawing the capital punishment aspect of the right, but not life imprisonment without the possibility of release as a sentence for children. One country, Iraq, expressed its prohibition of capital punishment and life imprisonment without the possibility of parole, but then the Committee response revealed that children can receive the death penalty for a crime they committed while under age 18 and wait until they turn 18 to be killed. The 2015 Committee response expresses concern that there are, "Reports of girls sentenced to death being held in the Karrada juvenile detention facility until they turn 18 and then being transferred to death row, despite the Juvenile Welfare Act not permitting life imprisonment or the death penalty for children" (20). This committee response reveals the contradiction between the two documents, as juvenile justice was not discussed at all in the 2014 country report, and that there appears to be a disconnect between what is in the law and what is practiced.

In other cases countries only prohibited capital punishment, and relied on life without the possibility of parole for the most heinous crimes even when committed by a child. This trend can be represented by the Committee's 2015 response to Jamaica's 2013 report. The Committee expressed concern at "[t]he fact that children may still be sentenced to life imprisonment" (18). 


\section{Lack of Adequate Legal Aid for Children}

According to the data, children aren't given adequate legal aid in 19 out of 169 countries around the world. Out of 54 countries that discuss this right, there are a significant number of countries that still do not guarantee children with adequate legal aid. While some countries have legal safeguards for children, others don't provide free legal assistance to any of their citizens. In the NGO report from a number of Polish NGOs, it is revealed that juveniles don't have adequate legal assistance in the country. More prominently, Zambia's 2015 report reveals:

Although the right to legal representation is enshrined in the Constitution, Zambia wishes to state that it cannot guarantee the same to children. Insufficient human and financial resources have impacted negatively on the provision of legal representation generally [...] Zambia recognizes that there is need to empower the Legal Aid Board with resources to establish a department for juvenile representation in order to address the need to guarantee Children's right to legal representation. However, this needs adequate resources. (45)

The lack of legal aid in countries around the world is especially a problem for children who do not have the knowledge to understand legal terminology or court procedures. Some countries have the provisions in place, but do not have the resources, financial and human, to provide children with legal assistance trained in juvenile matters. Setting the Age of Criminal Responsibility Lower than the Recommended Level

The majority of countries (95 of 169) around the world have an age of criminal responsibility under 14 years which is the age the Committee recommends as the minimum age of criminal responsibility. There is no age of criminal responsibility in a handful of countries, but the lowest set age in several countries is as young as 7 years old. One recent example is 
Zimbabwe's 2015 report simply stating "the age of criminal responsibility is 7 years" (77). The Committee responded to this by expressing concern at "the very low age of criminal responsibility, which is currently 7 years of age" and recommending that Zimbabwe "raise the age of criminal responsibility in accordance with international standards" (20). The age of criminal responsibility being set at 7 years old means that children as young as 7 are being tried as adults in court for acts that they may or may not have understood as wrong at the time they committed them.

\section{Holding Children in Pre-trial Detention for Long Periods of Time}

The analysis showed that thirteen of the 169 countries hold children in pre-trial detention for long periods of time. Over half of the 23 countries that report on this right are not guaranteeing this right. In response to Italy's 2010 report, the Committee's response indicates concern over "prolonged pretrial detention" of minors. Similarly, the Committee's response to Bosnia and Herzegovina's 2011 report indicated that there were long pre-trial detention periods as well. This is an example of a right that was overlooked by the country in their reports, but was addressed as a concern by the Committee.

\section{THE PREVALENCE OF REPORTED COMPLIANCE ACROSS THE 7 RIGHTS}

While all seven rights were discussed in some context throughout the 169 countries, some rights were discussed much more prevalently than others (see Figure C-1). The vast majority of countries (128 out of the 169) reported the age of criminal responsibility in their country (right 6). This was by far the most reported on right overall, and the right with which the most countries were out of compliance. Despite the low age of criminal responsibility, this right was addressed in most of the reports. 
The right to protection against cruel, inhuman, or degrading treatment (right 1) was the second highest reported right overall with 89 of the 169 countries discussing this right, and the lack of effective legislation to prevent the practice from occurring was common. Many countries didn't openly admit to sentencing children to corporal punishment (although some countries did give detailed explanations of the regulations around corporal punishment in the country); however, the NGO "Global Initiative to End All Corporal Punishment” gave additional information on this subject for a majority of the countries. Even if corporal punishment isn't actively practiced the majority of countries aren't implementing laws and legislation to formally outlaw the practice.

Very closely following the protection against cruel, inhuman, or degrading treatment was, the right to separate facilities for youth offenders from adults (right 2). This right was discussed by just over half of the countries (88 out of 169), and the majority of those countries expressed that children were not separated from adults in all instances. While some countries discussed adequate separation of children and adults and others provided discussion as to why there wasn't full separation of children and adults, the majority of the countries that discussed this right were discussing the lack of its implementation.

The fourth most reported right (discussed in the reports of 58 out of 169 countries) was the protection against capital punishment and life imprisonment (right 4). Fewer than half of the countries discussed this right, but when it was discussed, the majority of countries were implementing this right. This right is discussed in a positive light in most of the reports as more countries are protecting children from capital punishment and life imprisonment. It is positive to note that a fair number of countries were able to provide information on this protection and its implementation. 
Following the protection against capital punishment and life imprisonment (discussed in the reports of 54 of the 169 countries) is the right to an attorney (right 5). Once again, more countries were implementing this right than not implementing this right. This implies that in many places around the world, children have access to adequate legal representation; however, there are still a fair number that are lacking this right (as discussed previously). This right is important to the larger protection of children's rights in trouble with the law, as legal representation helps to prevent further abuses due to a lack of understanding the juvenile justice system.

Second to last, the right to a fair and speedy trial (right 7) was discussed in very few (23 out of 169) reports overall. Between those that did and those that did not implement the provisions of this right, only a few more countries discussed not guaranteeing this right than guaranteeing this right. However, very few countries overall discussed this right. The right to a fair and speedy trial is important for keeping children out of the criminal justice system in an effort to limit their exposure to criminal lifestyles and help keep their lives normalized. Because this right was not discussed in any context for many countries, it makes it difficult to draw very many conclusions.

Finally, the least discussed right (19 out of 169 countries) was the right of children to maintain contact with their family (right 3 ). Very few countries discussed this right, and when they did discuss this right, countries largely mentioned the provisions that have been implemented to ensure that children have access to their families. Familial connections are important for children's post-incarceration success. However, this right, once again, was not discussed in many contexts; therefore, is hard to evaluate on a global level. 
These patterns in the coverage of rights help to show that some areas within juvenile justice are much more prominent in country discussions than others. This is important because the $\mathrm{CRC}$ sees these rights as equal, and includes them each as a provision to ensure that children in trouble with the law are kept in the best care, for the shortest amount of time, with appropriate access to help and support. Given that these rights are discussed unequally within the country reports, NGO reports, and Committee responses, it indicates that more work needs to be done to ensure all of the rights of children equally. 


\section{CHAPTER V: DISCUSSION}

Children in trouble with the law are a vulnerable population who are, in theory, protected through the CRC. In an effort to identify the "global range and patterns of national practices regarding children in trouble with the law," this study used the CRC country reports, NGO reports, and Committee responses to those reports. Through this analysis, it is clear that there is variation in the range of practices, but there are many patterns in the various reports as well. The ideal types of "high implementation" and "low implementation" (see Figure B-1) do not actually exist. Therefore, the countries were sorted into the categories of "High-Medium," "MidMedium," and "Low-Medium" (see Tables A-3, A-4, and A-5) to show that there were most, some, and few rights implemented in groups of countries around the world. Further, the patterns, including: allowing the corporal punishment of children in the juvenile justice system; continuing to sentence children with adults; not addressing children's right to remain in contact with their families; outlawing capital punishment, but not life sentences without the possibility of release; lack of adequate legal aid for children; setting the age of criminal responsibility below the recommended number; holding children in pre-trial detention for long periods of time, revealed that there are many countries which are not implementing rights in similar ways. These patterns offer insight into how children are being treated while in trouble with the law around the world. It is particularly important to note that any one of these patterns indicates problems with a criminal justice system, but the compounded effects of multiple human rights violations by the criminal justice system leads to further victimization of children (as discussed in the range of national practices). Given that these rights are sporadically addressed in the reports it is also hard to identify which rights are entirely overlooked or omitted, and which rights were addressed in a previous report, or have been addressed in another setting, for instance the report to the 
Committee on the Convention Against Torture. Finally, the prevalence of reported compliance across the 7 rights, showed that there are some rights that were discussed much more frequently than others, and that there are several rights that are neglected in the country reports, NGO reports, and Committee responses.

These findings reinforce the existing literature in that the ideal types of all and none do not exist in practice, as previously mentioned by Gran (2010). All of the countries have some rights they are implementing, and none of the countries are implementing all of the rights. Polonko et al. (2016) identified that the type of right (welfare, transitional, and equality rights) helped show how countries would implement the CRC. Welfare rights were implemented most frequently and equality rights were implemented least frequently. This study looked specifically at the transitional rights (which fall in between welfare and equality rights) of children in trouble with the law. Through this research it is clear that within the transitional right of children in trouble with the law there is variation in the implementation of the different rights within this category. There is more to this story than can be explained by the type of right (as identified by Polonko et al.) alone.

The human rights treaty compliance literature makes the case that type of government (democratic or autocratic), desire to be seen positively in the global community, the level of agreement with a treaty, and regional location helped to determine compliance with human rights treaties (Cardenas 2007; Hafner-Burton 2012). Previous authors have explored these factors and have found that no single indicator can be supported when looked at individually, and it is likely a mix of different indicators that determines the level of compliance with human rights treaties (De Mesquita et al. 2005; Hawkins 2004; Goodliffe et al. 2012; Landman and Larizza 2009; Nielsen and Simmons 2015; Powell and Staton 2009). This study suggests that previously 
discussed frameworks may not be the best fit for children's rights, but more specifically the rights of children in trouble with the law. Looking back to tables A-1, A-2, and A-3, the majority of countries are falling into the middle category of compliance, and there is no apparent indication that type of government, desire to be seen positively in the global community, the level of agreement with the treaty, and regional location have any bearing on where these countries fall; however, more research is needed in this regard.

The theory with the most support in explaining treaty compliance in the previous literature was the level of democracy (De Mesquita et al. 2005; Landman and Larizza 2009; Powell and Staton 2009). This indicator has been shown to influence compliance when looking at other human rights treaties, but in the context of the rights of children in trouble with the law, there is no obvious link between level of democracy and compliance with articles 37 and 40 of the CRC. It is relevant to note that no Western European countries, or other well-known industrialized countries fall in the low-medium category, but there are some African and fewer industrialized countries that were identified as falling in the high-medium category. This observation indicates that the categories relevant to other human rights treaty compliance may not be an applicable framework for children's rights, but more specifically to the rights of children in trouble with the law; however, more research is needed to further identify the causes of compliance and non-compliance.

The literature revealed a lack of research on juvenile justice on a global level, and research pertaining to children's rights utilizing human rights compliance theory. Given this gap, the current study laid the foundation for future studies, and was able to identify that there are variations in how compliant countries are to the $\mathrm{CRC}$ overall and there are some rights within this subsection of rights that countries are less compliant with than others. Researchers should 
not be solely focusing on the overall reported compliance of countries as there is variation within the smaller categories of rights as well.

This implies that rights should be looked at on an individual basis and considered collectively to understand the variation in implementation. Based on the reported levels of compliance, children in trouble with the law are still facing many injustices because of the overall lack of implementation of rights in some places around the world, but children all over the world aren't necessarily guaranteed the right to a fair and speedy trial, the right to maintain contact with family members, protection against capital punishment, the right to an attorney, protection from corporal punishment or detention with adult convicts, or protection of an adequate age (over 14 years old) of criminal responsibility.

\section{FUTURE RESEARCH}

Future research should push the field forward by exploring the less prevalent rights for children in trouble with the law, namely, the right to maintain contact with family and the right to a fair and speedy trial. These two rights in particular were sparsely discussed in the three reports, but it is still unclear as to why these rights, specifically, would be controversial or difficult to implement. The right to maintain contact with family is a pivotal right for children because it allows for a more successful transition home. The lack of a fair and speedy trial is particularly troubling as it indicates that the right is not being recognized. Long pretrial detention exposes children to life in institutions and in some cases a criminal mentality. The documents used in this study are insufficient for finding out more information on these two rights which suggests that future research would need to address these rights using other sources. While the right to maintain contact with family and the right to a fair and speedy trial were the least 
discussed rights in this study, reported compliance of the other 5 rights should be looked at in more detail as well and considered longitudinally.

Further, future research needs to address the lack of theory surrounding children's rights but more specifically juvenile justice around the world. The current research was able to identify that the rights of children in trouble with the law don't fit within the previously identified categories of human rights compliance, and that individual rights vary in their level of implementation. The literature specific to children's rights needs to explore whether children's rights as a whole don't fit neatly into the previously established human rights compliance literature, or if it is specific to the rights of children in trouble with the law.

\section{LIMITATIONS}

There are several limitations of the data used in this study that should be brought to light. First, the validity of these reports comes into question because of the different countries' governments, NGOs, and the Committee that put them together. Each entity has their own agendas and ideas about what is and is not acceptable laws and practices regarding the treatment of children in trouble with the law, and some countries may try to be deceitful and misleading in their reports to portray the best image of themselves. While noting this limitation, these reports are the best available data to address children in trouble with the law around the world. They are

the only standardized, publicly available documents that discuss children in trouble with the law. Many authors have identified that the basis for international juvenile justice is the $\mathrm{CRC}$ and that the best available data comes from these country, NGO, and Committee reports (Kilkelly 2008; Ruck et al. 2014; Polonko et al 2016; Zalkind and Simon 2004; Zimring 2015).

Second, because of a language barrier, I was only able to use the country reports, the NGO reports, and the Committee responses that were in English, and I was not able to use any 
outside data from different countries to support and augment the current knowledge. There would be translation issues and availability issues for access to and understanding of other official country reports and data that might supplement the reports in this analysis. Therefore, this reinforces the first point that the $\mathrm{CRC}$ country, $\mathrm{NGO}$, and Committee reports are currently the best available data on juvenile justice around the world.

\section{CONCLUSION}

The United Nations Convention on the Rights of the Child is an important instrument for understanding juvenile justice systems around the world. Through this research I hoped to gain a more comprehensive understanding of official and current national practices regarding children in trouble with the law across the world. This study is the first to qualitatively analyze these documents; thus this is the first study attempting to identify the state of juvenile justice systems around the world. There are varied levels of implementation of the rights of children in trouble with the law around the world, and some specific rights are more neglected than others. Some of the rights of children in trouble with the law are being neglected and overlooked, and others are being discussed and not properly implemented, but in both cases, there is not a single country or region that can be identified as not having appropriately implemented rights. This is a global problem in which the rights of children in trouble with the law are at risk of being neglected, overlooked, and not discussed. 


\section{REFERENCES}

Ame, Robert Kwame. 2011. "The Rights of Children in Conflict with the Law in Ghana." International Journal of Children's Rights 19:271-293.

Bartollas, Clemens, and Frank J. Schmalleger. 2013. Juvenile Delinquency (1st ed.). Upper Saddle River, NJ: Pearson.

Cardenas, Sonia. 2007. Conflict and Compliance: State Responses to International Human Rights Pressure. Philadelphia, PA:University of Pennsylvania Press.

De Mesquita, Bruce Bueno, George W. Downs, Alastair Smith, and Feryal Cherif. 2005.

"Thinking Inside the Box: A Closer Look at Democracy and Human Rights." International Studies Quarterly 49(3):439-458.

Goldson, Barry, and Ursula Kilkelly. 2013. "International Human Rights Standards and Child Imprisonment: Potentialities and Limitations." International Journal of Children's Rights $21: 345-371$.

Goodliffe, Jay, Darren Hawkins, Christine Horne, and Daniel Nielsen. 2012. "Dependence Networks and the International Criminal Court.” International Studies Quarterly $56(1): 131-147$

Gran, Brian. 2010. Comparing Children's Rights: Introducing the Children's Rights Index.” International Journal of Children's Rights 18:1-17

Hafner-Burton, Emilie. 2012. "International Regimes for Human Rights." Annual Review of Political Science. 15:265-286.

Hawkins, Darren. 2004. “Explaining Costly International Institutions: Persuasion and Enforceable Human Rights Norms.” International Studies Quarterly 48(4):779-804. 
Hesse-Biber, Sharlene Nagy, and Patricia L. Leavy. 2011. The Practice of Qualitative Research. Thousand Oaks, CA: Sage Publications.

Howell, James C. 2009. Preventing and Reducing Juvenile Delinquency: A Comprehensive Framework Second Edition. Thousand Oaks, CA: Sage Publications.

Kilkelly, Ursula. 2008. "Youth Justice and Children's Rights: Measuring Compliance with International Standards." Youth and Justice 8:187-192.

Landman, Todd, and Marco Larizza. 2009. "Inequality and Human Rights: Who Controls What, When, and How.” International Studies Quarterly 53(3):715-736.

Lofland, John, and Lyn H. Lofland. 1995. Analyzing Social Settings. Belmont, CA:Wadsworth Publishing.

Lynch, Nessa. 2008. "Youth Justice in New Zealand: A Children's Rights Perspective.” Youth Justice 8:215-228.

Nielsen, Richard A., and Beth A. Simmons. 2015. "Rewards for Ratification: Payoffs for Participating in the International Human Rights Regime?” International Studies Quarterly 59(2):197-208.

Nofziger, Stacy. 2009. "Victimization and the General Theory of Crime". Violence \& Victims 24(3): 337-350.

Polonko, Karen A., Lucien X. Lombardo, and Ian M. Bolling. 2016. “Law Reform, Child Maltreatment and the un Convention on the Rights of the Child." International Journal of Children's Rights 24:29-64

Powell, Emilia Justyna, and Jeffrey K. Staton. 2009. “Domestic Judicial Institutions and Human Rights Treaty Violations." International Studies Quarterly 53(1):149-174. 
Ratify OP3 CRC. 2014. "Ratify OP3 CRC to Provide International Justice to Children!"

International Coalition for the OPCRC on a Communications Procedure. Retrieved from http://ratifyop3crc.org/

Ruck, Martin D., Daniel P. Keating, Elizabeth M. Saewyc, Felton Earls, and Asher Ben-Arieh. 2014. "The United Nations Convention on the Rights of the Child: Its Relevance for Adolescents." Journal of Research on Adolescence 25:1-14.

Storgaard, Anette. 2004. "Juvenile Justice in Scandinavia." Journal of Scandinavian Studies in Criminology \& Crime Prevention 5:188-204.

United Nations. 1989. Convention on the Rights of the Child.

United Nations, Division for Social Policy and Development Youth. (2011). "Fact Sheet on Juvenile Justice." World Youth Report. Retrieved from http://www.un.org/esa/socdev/unyin/documents/wyr11/FactSheetonYouthandJuvenileJus tice.pdf

Volonakis, Diana. 2015. “CRC Ratification by Somalia.” Children's Rights.Org. Retrieved from http://www.childsrights.org/en/news/editorials/533-crc-ratification-by-somalia

Zalkind, Paola, and Rita J. Simon. 2004. Global Perspectives on Social Issues: Juvenile Justice Systems. Lanham, MD: Lexington Books.

Zimring, Franklin E., Maximo Langer, and David S. Tanenhaus. 2015. Juvenile Justice in Global Perspective. New York, NY: New York University Press. 


\section{APPENDIX A: TABLES OF COUNTRIES}

\begin{tabular}{|l|l|l|l|l|l|}
\hline \multicolumn{2}{|l|}{ Table A-1: List of CRC-ratifying Countries Excluded from Analysis } \\
\hline $\begin{array}{l}\text { Antigua \& } \\
\text { Barbuda }\end{array}$ & Cape Verde & $\begin{array}{l}\text { Equatorial } \\
\text { Guinea }\end{array}$ & Libya & $\begin{array}{l}\text { Saint Kitts } \\
\text { and Nevis }\end{array}$ & $\begin{array}{l}\text { Trinidad and } \\
\text { Tobago }\end{array}$ \\
\hline Bahamas & $\begin{array}{l}\text { Central } \\
\text { African } \\
\text { Republic }\end{array}$ & Gabon & Micronesia & San Marino & Uganda \\
\hline Barbados & Comoros & Holy See* & Nauru & $\begin{array}{l}\text { Solomon } \\
\text { Islands }\end{array}$ & Vanuatu \\
\hline Belize & Cote d'Ivoire & Kosovo & Palau & Somalia & \\
\hline Botswana & Dominica & Lesotho & $\begin{array}{l}\text { Papua New } \\
\text { Guinea }\end{array}$ & Tonga & \\
\hline
\end{tabular}

*This country did not provide enough information in the country, NGO, or Committee response report to be included in the analysis. 


\begin{tabular}{|l|l|l|}
\hline \multicolumn{3}{|l|}{ Table A-2: Countries with NGO Reports (Alphabetically) } \\
\hline Countries with NGO Reports & $\begin{array}{l}\text { Number of relevant NGO } \\
\text { Reports/total NGO Reports }\end{array}$ \\
\hline Albania & $2 / 5$ & \\
\hline Algeria & $2 / 3$ & Confirms \\
\hline Armenia & $1 / 2$ & Confirms \\
\hline Austrailia & $3 / 6$ & Confirms \\
\hline Austria & $1 / 3$ & Confirms \\
\hline Azerbaijan & $1 / 1$ & Confirms \\
\hline Bangladesh & $4 / 9$ & Contradicts \\
\hline Bosnia and Herzegovina & $1 / 1$ & Confirms \\
\hline Brazil & $1 / 2$ & Confirms \\
\hline Brunei Darussalam & $1 / 1$ & Confirms \\
\hline Bulgaria & $1 / 4$ & Confirms \\
\hline Chile & $4 / 8$ & Confirms \\
\hline China & $3 / 16$ & Confirms \\
\hline Colombia & $2 / 9$ & Confirms \\
\hline Republic of the Congo & $1 / 2$ & Contradicts \\
\hline Cook Islands & $1 / 2$ & Confirms \\
\hline Croatia & $1 / 1$ & Confirms \\
\hline Cyprus & $1 / 4$ & Confirms \\
\hline Dominican Republic & $1 / 5$ & Confirms \\
\hline Estonia & $0 / 3$ & Confirms \\
\hline Ethiopia & $1 / 4$ & Not Relevant \\
\hline Fiji & $1 / 1$ & Confirms \\
\hline France & $4 / 11$ & Confirms \\
\hline Gambia & $2 / 2$ & Confirms \\
\hline Germany & $1 / 12$ & Confirms \\
\hline Ghana & $2 / 5$ & Confirms \\
\hline Greece & $3 / 7$ & Confirms \\
\hline Guinea & $0 / 1$ & Confirms \\
\hline Guinea Bissau & $0 / 2$ & Not Relevant \\
\hline Haiti & $1 / 1$ & Not Relevant \\
\hline Hungary & $2 / 6$ & Confirms \\
\hline India & $0 / 4$ & Confirms \\
\hline Indonesia & $0 / 5$ & Not Relevant \\
\hline Iran & $5 / 10$ & Not Relevant \\
\hline Iraq & $0 / 4$ & Confirms \\
\hline Ireland & $1 / 3$ & Not Relevant \\
\hline Israel & $1 / 8$ & Confirms \\
\hline Jamaica & $2 / 3$ & Confirms \\
\hline Jordan & $0 / 2$ & Confirms \\
\hline Kazakhstan & $1 / 1$ & Not Relevant \\
\hline Kenya & $1 / 6$ & Confirms \\
\hline & & Confirms \\
\hline & & \\
\hline & & \\
\hline & & \\
\hline
\end{tabular}

(Table Continues) 
Table A-2: Countries with NGO Reports (Alphabetically) Continued

\begin{tabular}{|c|c|c|}
\hline Kuwait & $1 / 4$ & Confirms \\
\hline Kyrgyz Republic & $2 / 4$ & Confirms \\
\hline Latvia & $0 / 3$ & Not Relevant \\
\hline Liberia & $1 / 1$ & Confirms \\
\hline Lithuania & $3 / 5$ & Confirms \\
\hline Luxembourg & $1 / 1$ & Confirms \\
\hline Madagascar & $1 / 2$ & Confirms \\
\hline Maldives & $4 / 5$ & Confirms \\
\hline Malta & $0 / 2$ & Not Relevant \\
\hline Mauritius & $2 / 3$ & Confirms \\
\hline Mexico & $1 / 2$ & Confirms \\
\hline Monaco & $1 / 2$ & Confirms \\
\hline Morocco & $1 / 8$ & Confirms \\
\hline Myanmar & $2 / 3$ & Confirms \\
\hline Namibia & $1 / 1$ & Contradicts \\
\hline Nepal & $3 / 6$ & Confirms \\
\hline Netherlands & $1 / 5$ & Confirms \\
\hline New Zealand & $0 / 2$ & Not Relevant \\
\hline Niue & $1 / 2$ & Confirms \\
\hline Oman & $1 / 1$ & Confirms \\
\hline Pakistan & $2 / 4$ & Confirms \\
\hline Peru & $1 / 2$ & Contradicts \\
\hline Poland & $1 / 2$ & Confirms \\
\hline Portugal & $2 / 2$ & Confirms \\
\hline Russian Federation & $4 / 11$ & Confirms \\
\hline Rwanda & $1 / 3$ & Confirms \\
\hline Saint Lucia & $3 / 5$ & Confirms \\
\hline Samoa & $1 / 1$ & Contradicts \\
\hline Sao Tome Principia & $1 / 1$ & Confirms \\
\hline Senegal & $0 / 1$ & Not Relevant \\
\hline Sierra Leone & $3 / 6$ & Confirms \\
\hline Slovakia & $1 / 2$ & Confirms \\
\hline Slovenia & $1 / 3$ & Confirms \\
\hline South Africa & $0 / 4$ & Not Relevant \\
\hline Surname & $1 / 1$ & Contradicts \\
\hline Sweden & $2 / 10$ & Confirms \\
\hline Switzerland & $3 / 13$ & Confirms \\
\hline Tanzania & $4 / 11$ & Confirms \\
\hline Thailand & $1 / 1$ & Confirms \\
\hline Timor-Leste & $2 / 5$ & Confirms \\
\hline Togo & $1 / 1$ & Confirms \\
\hline Turkmenistan & $0 / 2$ & Not Relevant \\
\hline
\end{tabular}

(Table Continues) 
Table A-2: Countries with NGO Reports (Alphabetically) Continued

\begin{tabular}{|l|l|l|}
\hline Tuvalu & $2 / 2$ & Confirms \\
\hline United Arab Emirates & $1 / 2$ & Confirms \\
\hline United Kingdom & $5 / 16$ & Confirms \\
\hline Uruguay & $0 / 2$ & Not Relevant \\
\hline Uzbekistan & $1 / 2$ & Confirms \\
\hline Vietnam & $3 / 5$ & Confirms \\
\hline Yemen & $2 / 3$ & Confirms \\
\hline Zambia & $1 / 2$ & Confirms \\
\hline Zimbabwe & $1 / 1$ & Confirms \\
\hline
\end{tabular}


Table A-3: High-Medium Compliance Countries (alphabetically and vertically organized)

\begin{tabular}{|c|c|c|c|}
\hline Andorra & Germany & Mali & Serbia \\
\hline Bulgaria & Guinea Bissau & Niue & South Africa \\
\hline Costa Rica & Iceland & Norway & Spain \\
\hline Egypt & Italy & Oman & Tunisia \\
\hline Finland & Liechtenstein & Poland & \\
\hline
\end{tabular}




\begin{tabular}{|c|c|c|c|}
\hline Afghanistan & Bolivia & Cyprus & Ghana \\
\hline Algeria & $\begin{array}{l}\text { Bosnia and } \\
\text { Herzegovina }\end{array}$ & Czech Republic & Greece \\
\hline Angola & Brazil & Denmark & Grenada \\
\hline Argentina & Brunei Darussalam & Dominican Republic & Haiti \\
\hline Armenia & Cameroon & $\begin{array}{l}\text { East Timor (Timor- } \\
\text { Leste) }\end{array}$ & Honduras \\
\hline Australia & Canada & Ecuador & Hungary \\
\hline Austria & Chad & Eritrea & India \\
\hline Azerbaijan & Chile & Estonia & Indonesia \\
\hline Bahrain & China & Ethiopia & Ireland \\
\hline Bangladesh & Colombia & Fiji & Israel \\
\hline Belarus & Cook Islands & France & Jamaica \\
\hline Belgium & Croatia & Gambia & Japan \\
\hline Bhutan & Cuba & Georgia & Kenya \\
\hline
\end{tabular}

(Table Continues) 


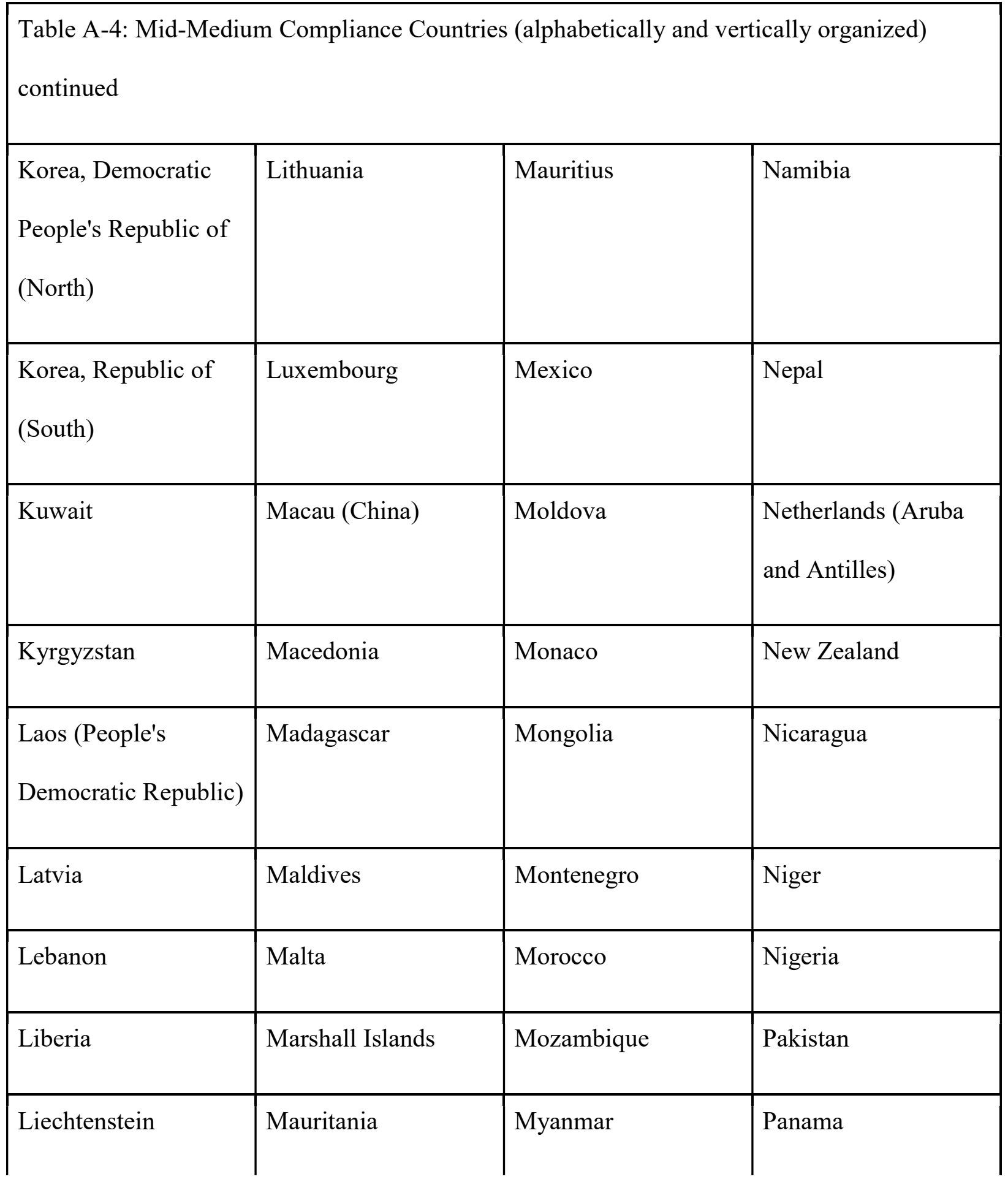

(Table Continues) 


\begin{tabular}{|c|c|c|c|}
\hline Paraguay & Samoa & Syrian Arab Republic & Uzbekistan \\
\hline Peru & Senegal & Tajikistan & Venezuela \\
\hline Philippines & Sierra Leone & $\begin{array}{l}\text { Tanzania (United } \\
\text { Republic of) }\end{array}$ & Vietnam \\
\hline Portugal & Singapore & Thailand & Yemen \\
\hline Qatar & Slovakia & Turkmenistan & Zambia \\
\hline Romania & Slovenia & Tuvalu & Zimbabwe \\
\hline Russian Federation & Sri Lanka & Ukraine & \\
\hline Rwanda & Suriname & United Arab Emirates & \\
\hline Saint Lucia & Sweden & United Kingdom & \\
\hline $\begin{array}{l}\text { Saint Vincent and the } \\
\text { Grenadines }\end{array}$ & Switzerland & Uruguay & \\
\hline
\end{tabular}


Table A-5: Low-Medium Compliance Countries (alphabetically and vertically organized)

\begin{tabular}{|c|c|c|c|}
\hline Albania & $\begin{array}{l}\text { Democratic } \\
\text { Republic of the } \\
\text { Congo }\end{array}$ & Jordan & $\begin{array}{l}\text { Sao Tome and } \\
\text { Principe }\end{array}$ \\
\hline Benin & Djibouti & Kazakhstan & Seychelles \\
\hline Burkina Faso & El Salvador & Kiribati & Sudan \\
\hline Burundi & Guinea & Malawi & Swaziland \\
\hline Cambodia & Iran & Malaysia & Togo \\
\hline Congo & Iraq & Saudi Arabia & Turkey \\
\hline
\end{tabular}


THE LAW
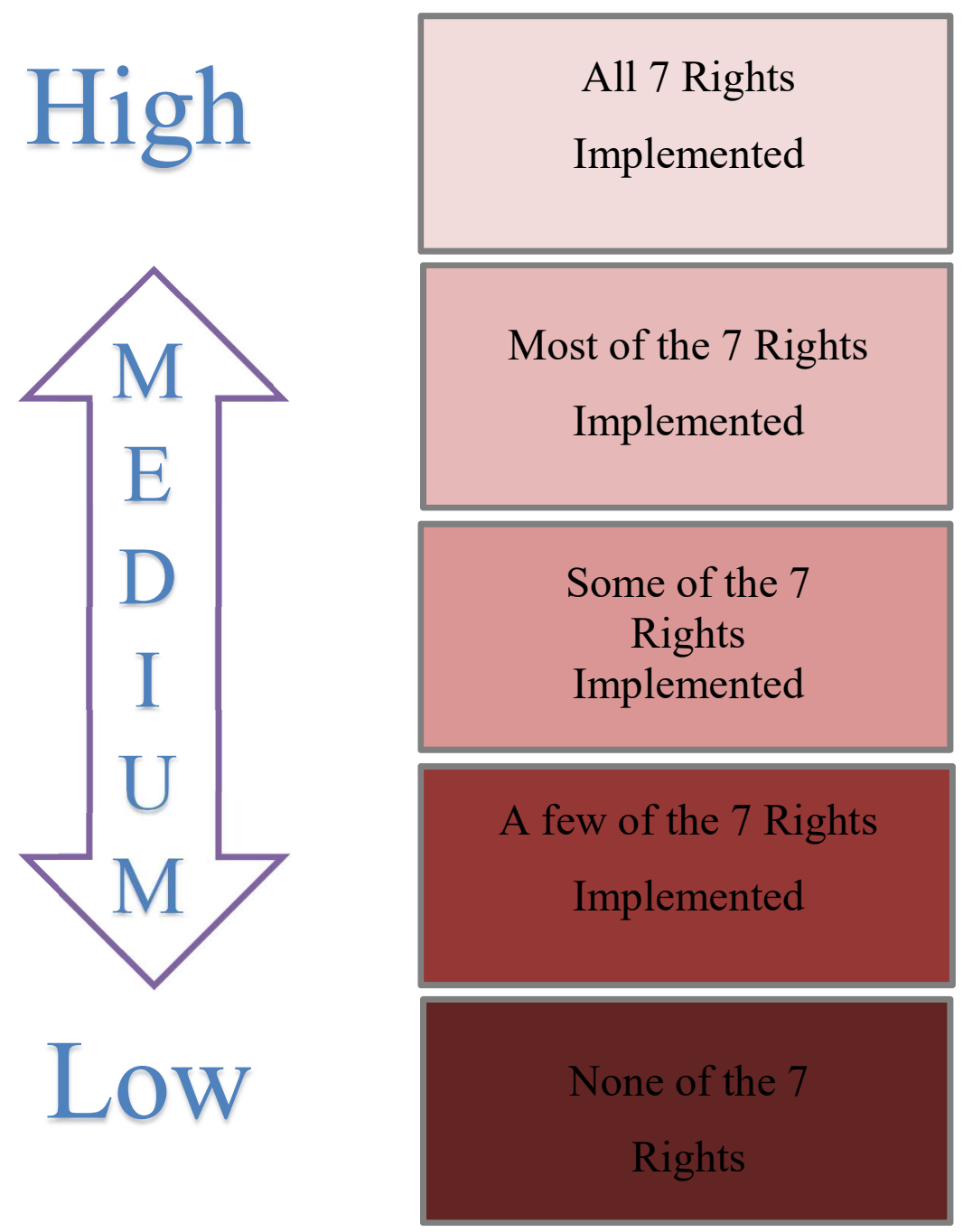

Figure B-1: Range of Rights for Children in Trouble with the Law

Figure B-1: This figure depicts the range of reported country compliance regarding the rights of children in trouble with the law. The green box at the top with "All 7 Rights Implemented" and the red box at the bottom with "None of the 7 Rights Implemented" are hypothetical or ideal 
types. The middle 3 boxes depict the actual range High-Medium, Mid-Medium, and LowMedium (respectively), that the 170 countries fall into. 


\section{APPENDIX C: FIGURE C-1: PREVALENCE OF REPORTED COMPLIANCE OF}

\section{COUNTRIES BY RIGHT}

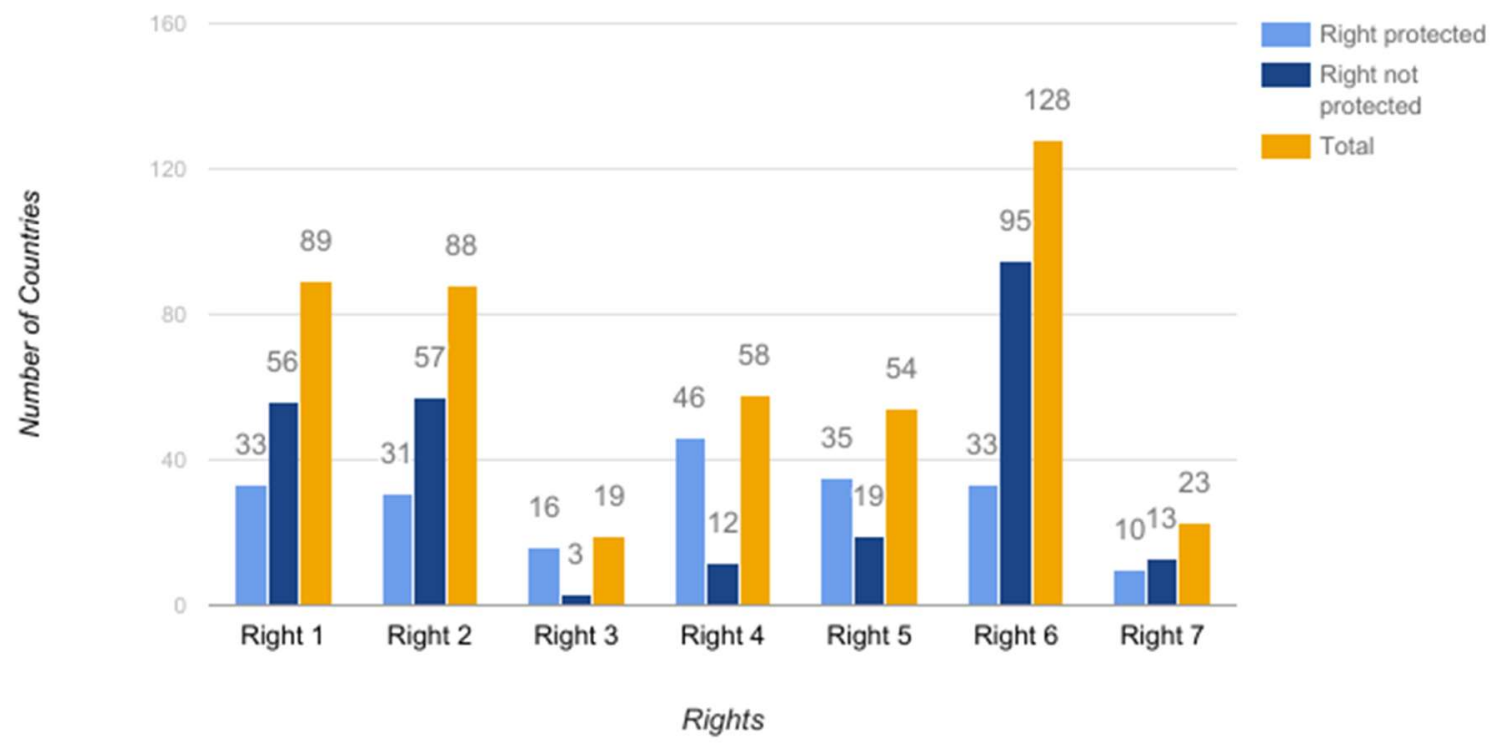

Figure C-1: Prevalence of Reported Compliance of Countries by Right

Figure C-1: Right 1: protection against cruel, inhuman and degrading punishment; Right 2: right to detention separate from adults; Right 3: right to maintain contact with family; Right 4: protection against capital punishment or life imprisonment without the possibility of release; Right 5: Right to an attorney or legal representation; Right 6: Right to an age of criminal responsibility set by the government; Right 7: Right to a fair and speedy trial. 